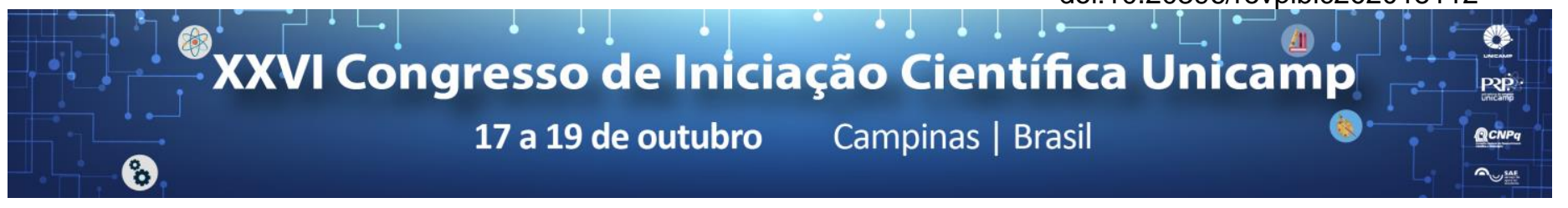

\title{
Audiências Públicas como forma de resistência entre comunidades tradicionais do Vale do Ribeira- SP
}

\section{Ana Carolina Oliveira Marcucci ${ }^{\star}$}

\section{Resumo}

Esta pesquisa se propõe a realizar uma etnografia do ciclo de audiências públicas sobre educação escolar diferenciada, que ocorreu na região do Vale do Ribeira-SP. O objetivo é analisar o papel mobilizador destas audiências, com atenção aos repertórios, em especial a cultura, história e identidade como intrumentos de reivindicação, bem como as questões demandadas e as trocas entre os diversos atores. Ademais, propões-se dar continuidade a divulgação das denúncias a partir da elaboração de um mapa interativo online.

\section{Palavras-chave:}

audiência pública, Vale do Ribeira, educação diferenciada

\section{Introdução}

No ano de 2015, em um contexto de fechamentos de escolas rurais e de discussão local sobre educação, comunidades tradicionais do Vale do Ribeira (quilombolas, indígenas, caiçaras, caboclos, etc.) foram protagonistas no ciclo de audiências públicas sobre educação escolar diferenciada que ocorreu na região. As principais falas se organizaram em torno de a) reivindicações por uma educação escolar diferenciada, ou seja, por uma educação que leve em consideração as especificidades históricas, culturais, espaciais e de conteúdo das populações; e b) denúncias sobre problemas infraestruturais, de transporte, merenda, entre outros, que atingem diariamente os alunos e comprometem a permanência das comunidades na região.

Os interlocutores acionaram o compartilhamento de história, território, tradição, autonomia e identidade como instrumentos ativos de luta e de reivindicação. Isso configurou uma rede de falas que articularam ações, memórias, vínculos, cultura e resistência no processo de cobrança por um sistema educacional que julgam adequado a realidade local.

Assim, neste trabalho procurei examinar como o espaço da audiência pública propiciou as comunidades a se articularem em uma rede de falas, e de trocas de informações e frentes de ação, me atentando as linguagens, repertórios, e questões demandadas. Além disso, analiso como as diversas colaborações e disputas em torno das especificidades culturais, étnicas e históricas são usadas no repertório das populações tradicionais.

Ademais, para dar continuidade a divulgação dos diagnósticos e denúncias, organizei de um mapa interativo online, em que as denúncias das comunidades são agregadas a informações geográficas (figura 1).

\section{Resultados e Discussão}

A execução deste trabalho foi feito por meio da análise de videogravações das quatro audiências públicas, totalizando dezesseis horas de registro. Para tal, não usei imediatamente o recurso de transcrição, e sim busquei otimizar a atenção de análise, assistindo a cada fala pausadamente, descrevendo os pontos levantados pelo informante, me atentando as expressões e discursos. Para elaboração do mapa, utilizei a plataforma de sistema de informação geográfica ArcGis, cujo layout escolhido foi o "storymap", pois permite agregar informações escritas, vídeos e fotos ao mapa.

Figura 1. Mapa interativo "EDVCA Vale do Ribeira"

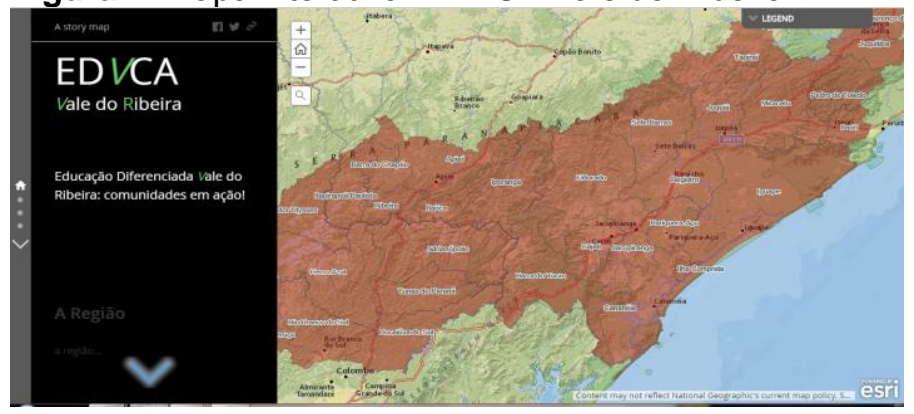

Figura 2. Audiência Pública em Eldorado -SP

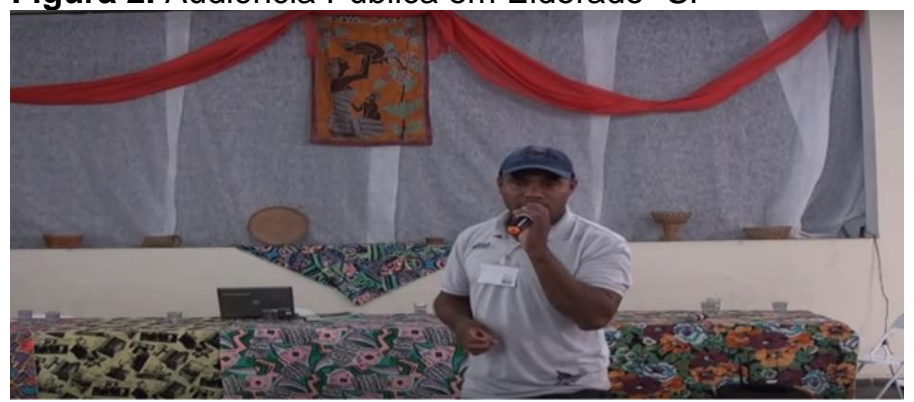

Conclusões

Durante os encontros que se deram as audiências foi possível perceber que certos elementos culturais foram acentuados pelas comunidades, de forma a responder as suas demandas políticas e econômicas atuais e cumprir uma função de contraste (Carneiro da Cunha, 2017 p. 242) ${ }^{1}$. Portanto, as especificidades culturais e étnicas foram utilizadas também como instrumento político das comunidades tradicionais para a reivindicação de direitos (Almeida, 2007) ${ }^{2}$.

\section{Agradecimentos}

Agradeço ao programa CNPq/PIBIC por financiar e incentivar esta pesquisa.

${ }^{1}$ CARNEIRO DA CUNHA, M. Cultura com aspas e outros ensaios. São Paulo, Editora Ubu, 2017

${ }^{2}$ ALMEIDA, Mauro W. B. de. Narrativas agrárias e a morte do campesinato. Ruris. Campinas, v. 1, n 2, pp. 157-186, 2007. 